\title{
CONTRIBUTEURS/ CONTRIBUTORS
}

Evgeniya Bobrovnik has received both a B.Ed. and M.Ed. from the University of Ottawa and has just completed her interim report. Her research focuses on equity and representation in higher education.

Christine Couture est professeure au Département des sciences de l'éducation à l'Université du Québec à Chicoutimi (UQAC). Spécialiste en didactique des sciences et des classes multi-âges, elle travaille principalement selon l'approche de recherche collaborative. Co-chercheure du projet TableauST, Professeure Couture a élaboré un cadre conceptuel pour aider à la caractérisation des critères gagnants et s'est surtout consacrée au travail de développement des douze exemples de pratiques avec les enseignants québécois. Elle privilégie l'établissement de communautés d'apprentissage pour le développement des pratiques en sciences et technologie et mobilise cette expertise dans d'autres contextes (classes multi-âges, modèles d'accompagnement).

Brad Daly is a 2nd year MA candidate studying at the University of Ottawa under the supervision of Dr. Nick Gazzola. Brad is conducting research on the experience of Counselling Psychology students during their internship.

Alexander Davis is a 1st year PhD student studying at the University of Ottawa under the supervision of Dr. Joel Westheimer. Alexander is researching the commercial relationship between digital classroom materials and classroom learning.

Liliane Dionne est une professeure agrégée à la Faculté d'éducation de l'Université d'Ottawa, et se spécialise en didactique des sciences et technologies et en méthodes de recherche qualitative appliquées à l'éducation. Chercheure principale du projet de recherche et conceptrice du TableauST.ca subventionné par le CRSH, Professeure Dionne a piloté toutes les étapes du projet avec les co-chercheures et les enseignants. Elle a travaillé sur le terrain avec la communauté d'apprentissage ontarienne à la caractérisation et à l'identification de près de quarante pratiques gagnantes qui sont partagées dans le site Web. Professeure Dionne a été chercheure sur quatre projets financés par le CRSH dont deux comme chercheure principale. Ses publications savantes sur la didactique des sciences et sur les communautés d'apprentissage sont connues ici et internationalement.

Nick Gazzola is a Full Professor in the Faculty of Education at the University of Ottawa. Dr. Nick Gazzola teaches graduate courses in Counselling Psychology and conducts research in individual counselling identity, counselling collective identity, counselling supervision processes, and the experience of the therapist in the process of counselling.

Carol Lee is a 3rd year PhD candidate studying at the University of Ottawa under the supervision of Dr. Nicholas Ng-A-Fook. Carol is researching how collaborative child authorship may foster reconciliation between Indigenous and nonIndigenous students. She has been a member of the Jean-Paul Dionne Symposium Organizing Committee and has served as Editor-in-Chief (English) of the education JOURNAL de l'education and the Actes du SJPD/JPDS Proceedings. 
Megan Lummiss is a 1st year PhD student studying at the University of Ottawa under the supervision of Dr. Bernard Andrews. While the submission for this journal is based on her MA thesis where she explored the self-concept of G/LD students, her current research focuses on the development of self-identity through music-making experiences.

Enyonam Norgbey is a third year PhD candidate studying at the University of Ottawa, Faculty of education, under the supervision of Prof. Richard Maclure. Enyonam is researching science and technology education and gender policies and their impacts on women's experiences in graduate science and technology programs in two universities in Ghana, West Africa.

Lorraine Savoie-Zajc, professeure émérite à l'Université du Québec en Outaouais (UQ0), est reconnue pour son expertise en méthodes de recherche en éducation et avec les communautés d'apprentissage. Elle a participé au projet TableauST en contribuant plus spécifiquement comme conseillère principale du projet, et au travail de terrain avec la communauté d'apprentissage en Ontario. Auteure de nombreux ouvrages savants sur l'accompagnement de communautés d'apprentissage, la recherche-action et le changement en éducation, Professeure Savoie-Zajc est reconnue internationalement pour ses travaux.

Christine Suurtamm is a Full Professor of Mathematics Education and teaches in the areas of mathematics education, assessment and qualitative research. Her research focuses on the complexity of teachers' classroom practice. She is particularly interested in teachers' formative assessment practices as these are opportunities of attending and responding to students' mathematical thinking. Dr. Suurtamm has been the lead researcher on several Ontario Ministry of Education large-scale projects to examine mathematics teaching and learning. She is also Director of the Pi Lab, a research facility supported by the Canada Foundation for Innovation. She was the Canadian representative on the National Council of Teachers of Mathematics Board of Directors, the Co-Chair of the Ontario Ministry of Education Early Math Expert Panel, and Co-Chair of several international panels on assessment in mathematics education. She is also the recipient of several teaching and research awards including Excellence in Teaching, the Capital Educator's Award and the University of Ottawa Excellence in Education Award. She is currently the Vice-Dean Research and Professional Development in the Faculty of Education.

Evra Trought-Pitters completed a Bachelor of Arts, a Bachelor of Education, and a Master's in Education at York University She is currently pursuing graduate studies at Brock University where she researches Social Justice Black Educational Leadership in Ontario elementary schools. She has worked with the Toronto District School Board for twenty years as an elementary teacher and is currently teaching Grade 2. 